\title{
BDIX, Rat Strain
}

National Cancer Institute

\section{Source}

National Cancer Institute. BDIX, Rat Strain. NCI Thesaurus. Code C14387.

Strain widely used in carcinogenesis and teratogenesis studies. Highly susceptible to the transplacental induction of malignant tumors of the central nervous system by ethyl nitrosourea (Druckrey et al 1970). A transplantable monocytic-myeloid leukemia L5222 induced by ethyl nitrosourea has been used as a model for chemotherapy (Ivankovic and Zeller 1974). Transplantable colon tumor PROb grows prog ressively and metastasizes, whereas REGb grows slowly and is then rejected (Blottiere et al 1992a,b). 